\title{
Unraveling platelet function in inflammation and thrombosis
}

Citation for published version (APA):

Coenen, D. (2021). Unraveling platelet function in inflammation and thrombosis: Secretory pathways and vascular interactions. [Doctoral Thesis, Maastricht University]. Maastricht University. https://doi.org/10.26481/dis.20210625dc

Document status and date:

Published: 01/01/2021

DOI:

$10.26481 /$ dis.20210625dc

Document Version:

Publisher's PDF, also known as Version of record

\section{Please check the document version of this publication:}

- A submitted manuscript is the version of the article upon submission and before peer-review. There can be important differences between the submitted version and the official published version of record.

People interested in the research are advised to contact the author for the final version of the publication, or visit the DOI to the publisher's website.

- The final author version and the galley proof are versions of the publication after peer review.

- The final published version features the final layout of the paper including the volume, issue and page numbers.

Link to publication

\footnotetext{
General rights rights.

- You may freely distribute the URL identifying the publication in the public portal. please follow below link for the End User Agreement:

www.umlib.nl/taverne-license

Take down policy

If you believe that this document breaches copyright please contact us at:

repository@maastrichtuniversity.nl

providing details and we will investigate your claim.
}

Copyright and moral rights for the publications made accessible in the public portal are retained by the authors and/or other copyright owners and it is a condition of accessing publications that users recognise and abide by the legal requirements associated with these

- Users may download and print one copy of any publication from the public portal for the purpose of private study or research.

- You may not further distribute the material or use it for any profit-making activity or commercial gain

If the publication is distributed under the terms of Article $25 \mathrm{fa}$ of the Dutch Copyright Act, indicated by the "Taverne" license above, 
Cardiovascular diseases are currently still a major global burden, among others due to the complex pathophysiology and the involvement of different organs, tissues and cells. Platelets are important in the underlying disease mechanisms, mainly by connecting thrombosis and vascular inflammation. In this thesis, we aimed to provide a translational perspective and give new mechanistic insights of platelet function in multiple cardiovascular conditions, including atherosclerosis, stroke, heart failure, and arterial and venous thrombosis. Herein, we highlighted the importance of platelet interaction with leukocytes and endothelial cells, focusing on plateletderived secretory mediators and involved signalling pathways.

In Chapter 1, we presented the most important and relevant background information concerning platelet function in cardiovascular diseases and the interaction with the vascular system. We introduced main clinical problems, i.e. high recurrence rate of thrombotic events in stroke and myocardial infarction, high incidence of venous thrombosis, and lack of effective treatment for heart failure with preserved ejection fraction (HFpEF) due to poorly understood pathophysiology. There is an urgent need for new and/or alternative therapeutics which requires a better understanding of the cellular and molecular mechanisms behind the disease to be treated. In Chapter 2 we contributed to this by giving a comprehensive and clear overview of the interactions between platelets and inflamed endothelial cells. We focused on describing underlying mechanisms of three main processes herein: platelet adhesion, platelet activation and thrombus formation. Interestingly, different platelet receptors are involved in platelet adhesion under inflammatory conditions when compared to haemostasis. We also substantiated microfluidics as an appropriate technique to investigate these interactions in vitro while allowing an adequate representation of the in vivo processes. We integrated the mechanistic insights with essential methodological variables of microfluidic studies, while critically discussing the experimental interpretation and providing recommendations for reporting of these studies.

How and why platelets interact with vascular cells is extended to the clinical presentations atherosclerosis, atherothrombosis and plaque healing in Chapter 3. Predominantly based on evidence derived from in vivo animal experiments, we pointed out that platelets are interacting with extracellular matrix components, endothelial cells and leukocytes in all phases. In diseased, thrombo-inflammatory conditions, the physiological function of endothelial cells to prevent platelets from being activated, is inadequate. Phosphodiesterases (PDEs) are a key element in the endothelium-mediated platelets' inhibitory signalling pathways, which is why we studied whether inhibition of these enzymes would affect thrombotic and inflammatory platelet responses (Chapter 4). Platelet function was measured after whole blood or washed platelet incubation with the PDE3A inhibitor cilostazol or the PDE5 inhibitor tadalafil. We found that neither inhibitor altered platelet activation and thrombus formation on collagen type I. Strikingly, cilostazol and tadalafil suppressed platelet pro-inflammatory functions in several ways. More specifically, both PDE3A and PDE5 are involved in platelet interaction with inflamed endothelium, but only 
cilostazol decreased monocyte migration and direct platelet-monocyte interaction. The secretion of soluble molecules and vesicles are important in the interactive triad of platelets, endothelial cells and leukocytes. We found a reduced release of the platelet-derived chemokines CCL5 (RANTES) and CXCL4 (platelet factor 4) when inhibiting platelet PDE3A and PDE5. However, the secretion of platelet extracellular vesicles was solely altered by cilostazol, albeit only pro-coagulant vesicle release. Chapter 5 continues with the investigation of platelet chemokine release and monocyte recruitment to platelet releasate after exposure to common antiplatelet medication. Depending on the agonist, antiplatelet medication (aspirin, cangrelor, $\alpha_{\| 1} \beta_{3}$ antagonists, cilostazol and combinations) inhibited the release of either CCL5 or CXCL4 or both from platelets. After single antiplatelet therapy the platelet releasate did not alter monocyte recruitment. Interestingly, this was decreased after dual antiplatelet therapy with aspirin plus cilostazol and aspirin plus cangrelor, but not for the combination of cangrelor with cilostazol.

In Chapter 6, we examined whether platelet, endothelial, and leukocyte activation is altered in HFpEF patients with or without type 2 diabetes mellitus. At this moment, HFpEF is treated inadequately because of a poor understanding of the underlying disease pathophysiology. This is even further complicated due to the presence of comorbidities, such as hypertension and diabetes. We observed increased expression of plasma markers indicating endothelial activation (intercellular adhesion molecule-1 and vascular cell adhesion molecule-1) which correlated with the presence of atrial fibrillation. Remarkably, we detected decreased levels of platelet activation markers ( $\beta$-thromboglobulin, platelet factor 4 , and thrombospondin-1) in our HFpEF cohort, with the presence type 2 diabetes mellitus as an important factor in both increased endothelial and decreased platelet activation. Further studies should elucidate whether the reduced secretion of platelet-derived soluble molecules can be linked with platelet (dys)function and impaired interactions of platelets with endothelial cells and leukocytes. This is especially important because in our study leukocyte count correlated positively with the platelet activation markers.

The use of genome-wide association studies (GWAS) in thrombosis research has led to the discovery of possible genetic risk factors for cardiovascular diseases, such as MRAS for coronary artery disease, and FV Leiden in venous thrombosis. However, a large population still suffers from one or more cardiovascular events, accentuating the need for more and new determinants to be identified. We investigated in Chapter 7 whether and how solute carrier family 44 member 2 (SLC44A2) is involved in venous thrombosis. We noticed that the choice of the experimental model is essential and partly determines whether you are able to answer your research question. Specifically, we did not find SLC44A2 to have a major function in the development of thrombosis in a hypercoagulability model of venous thrombosis. Instead, the number of circulating neutrophils was larger in Slc44a2 deficient mice after thrombus formation. Therefore, we implemented a stenosis-induced thrombosis model, in which a main role for neutrophils is reserved. 
Slc44a2 deficiency resulted in smaller thrombi in murine veins. The composition of the developed thrombi in the SIc44a2 deficient mice was less platelet-rich than the thrombi in the wild type mice. Although we did not observe differences in platelet activation as such, we anticipate that platelet-neutrophil interactions are of importance in the involvement of SLC44A2 in venous thrombosis. Further investigation is required to unravel the exact mechanisms, but analysis from our group and other groups imply von Willebrand factor (VWF) as a connecting factor. It is proposed that the detrimental role of SLC44A2 in venous thrombosis either concerns a direct connection between endothelial-derived VWF and SLC44A2 on neutrophils or indirect, via the interference of platelets. In the latter situation, VWF binds to the GPIb receptor on platelets, which become primed to activation and can bind to neutrophils via the $\alpha_{\| 1 b} \beta_{3}-S L C 44 A 2$ interaction.

In almost all diseases and clinical presentations discussed in this thesis, a state of inflammation is present with concomitant increased platelet activation. In Chapter 8, we used network biology and pathway analysis to go through a phosphoproteomics dataset and discover proteins and signalling processes involved in platelet activation and the reversal hereof. We incorporated information from the existing dataset with Gene Ontology enrichment analysis, KEGG and Reactome pathways, the Uniprot and String database, a phosphorylation prediction tool and the Drugbank database and visualized this with Cytoscape, creating multiple clear protein-protein interaction networks and clusters. We revealed vesicle secretion and cytoskeletal reorganization as important processes in platelet activation. Furthermore, a number of proteins connected to those processes were selected to be possible interesting targets to switch platelet activation 'off'.

In the final Chapter 9 we discussed the most important findings of this thesis in relation to the current literature. We stressed out that platelets have key roles in the pathophysiology of cardiovascular diseases in which thrombosis and vascular inflammation are interwoven. Direct and indirect crosstalk between platelets and other vascular cells is essential in this, and in particular the secretion of granules, vesicles and molecules from platelets. 

Hart- en vaatziekten vormen momenteel nog een grote wereldwijde last, onder meer door de complexe pathofysiologie en de betrokkenheid van verschillende organen, weefsels en cellen. Bloedplaatjes zijn belangrijk in de onderliggende ziektemechanismen, voornamelijk door trombose en vaatontsteking met elkaar te verbinden. In dit proefschrift wilden we een translationeel perspectief bieden en nieuwe mechanistische inzichten geven in de bloedplaatjesfunctie bij meerdere hart- en vaatziekten, waaronder slagaderverkalking (atherosclerose), herseninfarct, hartfalen en arteriële en veneuze trombose. Hierin benadrukten we het belang van bloedplaatjesinteractie met leukocyten en endotheelcellen, waarbij we ons concentreerden op door bloedplaatjes uitgescheiden mediatoren en betrokken signaalroutes.

In Hoofdstuk 1 hebben we de belangrijkste en meest relevante achtergrondinformatie gepresenteerd over de plaatjesfunctie bij hart- en vaatziekten en de interactie met het vaatstelsel. We introduceerden de belangrijkste klinische problemen, dat wil zeggen een grote kans op herhaling van trombotische gevolgen bij hersen- en hartinfarct, hoge incidentie van veneuze trombose en gebrek aan effectieve behandeling voor hartfalen met behouden ejectiefractie (HFpEF) als gevolg van niet goed begrepen pathofysiologie. Er is een dringende behoefte aan nieuwe en/of alternatieve therapieën wat een beter begrip vereist van de cellulaire en moleculaire mechanismen achter de te behandelen ziekte. In Hoofdstuk 2 hebben we hieraan bijgedragen door een uitgebreid en duidelijk overzicht te geven van de interacties tussen bloedplaatjes en ontstoken endotheelcellen. We hebben ons gericht op het beschrijven van de onderliggende mechanismen van drie hoofdprocessen hierin: aanhechting van bloedplaatjes, de activatie hiervan en daaropvolgende trombusvorming. Interessant is dat in vergelijking met hemostase verschillende bloedplaatjesreceptoren betrokken zijn bij de aanhechting van bloedplaatjes onder inflammatoire omstandigheden. We hebben ook onderbouwd dat microfluïdica een geschikte techniek is om deze interacties buiten het lichaam te onderzoeken en tegelijkertijd een adequate weergave van de processen in het lichaam mogelijk te maken. We integreerden de mechanistische inzichten met essentiële methodologische variabelen van studies die microfluïdica gebruikten, terwijl we de experimentele interpretatie kritisch bespraken en aanbevelingen deden voor het rapporteren van deze studies.

Hoe en waarom bloedplaatjes een interactie aangaan met vasculaire cellen wordt uitgebreid tot de klinische presentaties atherosclerose, atherotrombose en plaque genezing in Hoofdstuk 3. Voornamelijk gebaseerd op bewijs afkomstig van dierexperimenten wezen we erop dat bloedplaatjes in alle fasen een interactie aangaan met extracellulaire matrixcomponenten, endotheelcellen en leukocyten. In pathologische omstandigheden, specifiek in de aanwezigheid van zowel trombose als ontsteking, is de fysiologische functie van endotheelcellen om te voorkomen dat bloedplaatjes worden geactiveerd, onvoldoende. Fosfodiësterases (PDE's) zijn een sleutelelement in de door endotheel gestuurde remmende signaalroutes van bloedplaatjes. Daarom hebben we onderzocht of remming van deze enzymen de 
trombotische en inflammatoire bloedplaatjesreacties zou beïnvloeden (Hoofdstuk 4). De plaatjesfunctie werd gemeten na toevoeging van de PDE3A-remmer cilostazol of de PDE5-remmer tadalafil aan bloed of geïsoleerde plaatjes. We ontdekten dat geen van beide remmers de activering van bloedplaatjes en trombusvorming op collageen type I veranderde. Opvallend was dat cilostazol en tadalafil de ontstekingsbevorderende functies van bloedplaatjes op verschillende manieren onderdrukten. Meer specifiek zijn zowel PDE3A als PDE5 betrokken bij de interactie van bloedplaatjes met ontstoken endotheel, maar alleen cilostazol verminderde de migratie van monocyten en de directe interactie tussen bloedplaatjes en monocyten. De secretie van oplosbare moleculen en vesikels is belangrijk in de interactieve drieeenheid van bloedplaatjes, endotheelcellen en leukocyten. We vonden een verminderde afgifte van de van bloedplaatjes afkomstige chemokinen CCL5 (RANTES) en CXCL4 (bloedplaatjesfactor 4) bij het remmen van PDE3A en PDE5 in bloedplaatjes. De secretie van extracellulaire vesikels van bloedplaatjes werd echter uitsluitend veranderd door cilostazol, zij het alleen stollingsbevorderende vesikelafgifte. Hoofdstuk 5 gaat verder met het onderzoek naar de afgifte van chemokinen uit bloedplaatjes en de aantrekking van monocyten naar door bloedplaatjes uitgescheiden producten na blootstelling aan veel voorkomende plaatjesactivatieremmers. Afhankelijk van de agonist remden plaatjesactivatieremmers (aspirine, cangrelor, $\alpha_{\| 1 b} \beta_{3}$-antagonisten, cilostazol en combinaties) de afgifte van ofwel CCL5 ofwel CXCL4 of beide uit bloedplaatjes. $\mathrm{Na}$ plaatjesactivatieremmende medicatie veranderden de door plaatjes uitgescheiden producten de rekrutering van monocyten niet. Interessant genoeg was dit wel verminderd na het combineren van deze medicatie met aspirine plus cilostazol en aspirine plus cangrelor, maar niet met de combinatie van cangrelor met cilostazol.

In Hoofdstuk 6 hebben we onderzocht of de activering van bloedplaatjes, endotheelcellen en leukocyten veranderd is bij HFpEF patiënten met of zonder diabetes mellitus type 2. Op dit moment wordt HFpEF inadequaat behandeld vanwege een slecht begrip van de onderliggende pathofysiologie van de ziekte. Dit is nog ingewikkelder door de aanwezigheid van comorbiditeiten, zoals hoge bloeddruk (hypertensie) en diabetes. We observeerden een verhoogde expressie van plasmamarkers die activering van endotheelcellen aangeven (intercellulair adhesiemolecuul-1 en vasculair celadhesiemolecuul-1), wat correleerde met de aanwezigheid van atriumfibrilleren. Opmerkelijk was dat we verminderde levels van activeringsmarkers van bloedplaatjes ( $\beta$-tromboglobuline, bloedplaatjesfactor 4 en trombospondine-1) ontdekten in ons HFpEF cohort, met de aanwezigheid van diabetes mellitus type 2 als een belangrijke factor bij zowel verhoogde endotheelals verminderde bloedplaatjesactivering. Verdere studies moeten uitwijzen of de verminderde secretie van oplosbare moleculen afkomstig van bloedplaatjes kan worden gekoppeld aan (dys)functie van bloedplaatjes en verminderde interacties van de bloedplaatjes met endotheelcellen en leukocyten. Dit is vooral belangrijk omdat in onze studie het aantal leukocyten positief correleerde met de activeringsmarkers van bloedplaatjes. 
Het gebruik van genoom-wijde associatie studies (GWAS) in tromboseonderzoek heeft geleid tot de ontdekking van mogelijke genetische risicofactoren voor hart- en vaatziekten, zoals MRAS voor coronaire hartziekte en FV Leiden bij veneuze trombose. Een grote populatie lijdt echter nog steeds aan een of meerdere hart- en vaatproblemen, wat de behoefte benadrukt om meer en nieuwe bepalende factoren te identificeren. In Hoofdstuk 7 hebben we onderzocht of en hoe solute carrier family 44 member 2 (SLC44A2) betrokken is bij veneuze trombose. We merkten dat de keuze van het experimentele model essentieel is en mede bepaalt of je in staat bent om je onderzoeksvraag te beantwoorden. Concreet vonden we dat SLC44A2 geen belangrijke functie heeft bij de ontwikkeling van trombose in een model van veneuze trombose met verhoogde bloedstolling. In plaats daarvan was het aantal circulerende neutrofielen groter in SIc44a2-deficiënte muizen na trombusvorming. Daarom hebben we een door vernauwing (stenose) geïnduceerd trombosemodel geïmplementeerd, waarin een hoofdrol voor neutrofielen is weggelegd. SIc44a2-deficiëntie resulteerde in kleinere stolsels in de aderen van de muis. De samenstelling van de ontwikkelde stolsels in de SIc44a2deficiënte muizen was minder rijk aan bloedplaatjes dan de stolsels in de wildtype muizen. Hoewel we geen verschillen in bloedplaatjesactivering als zodanig hebben waargenomen, verwachten we dat bloedplaatjes-neutrofielen interacties van belang zijn bij de betrokkenheid van SLC44A2 bij veneuze trombose. Verder onderzoek is nodig om de exacte mechanismen te ontrafelen, maar analyse van onze groep en andere groepen impliceert von Willebrand-factor (VWF) als een verbindende factor. Er wordt voorgesteld dat de schadelijke rol van SLC44A2 bij veneuze trombose ofwel betrekking heeft op een directe verbinding tussen van endotheelcellen afkomstig VWF en SLC44A2 op neutrofielen, ofwel indirect, via de tussenkomst van bloedplaatjes. In de laatste situatie bindt VWF aan de GPlb-receptor op bloedplaatjes, die aangezet worden tot activering en kunnen binden aan neutrofielen via de $\alpha_{\| 1 b} \beta_{3}-S L C 44 A 2$-interactie.

Bij bijna alle ziekten en klinische presentaties die in dit proefschrift worden besproken, is sprake van een ontstekingstoestand met gelijktijdige verhoogde bloedplaatjesactivering. In Hoofdstuk 8 hebben we netwerkbiologie en analyse van signaleringsroutes gebruikt om door een dataset te gaan en eiwitten en signaalprocessen te ontdekken die betrokken zijn bij de activering van bloedplaatjes en de omkering hiervan. We hebben informatie uit de bestaande dataset samengenomen met Gene Ontology-verrijkingsanalyse, KEGG- en Reactomesignaleringsroutes, de Uniprot- en String-database, een fosforyleringsvoorspellingstool en de Drugbank-database en hebben dit gevisualiseerd met Cytoscape, waardoor meerdere duidelijke eiwit-eiwit interactienetwerken en clusters zijn ontstaan. We onthulden de secretie van vesikels en de reorganisatie van het cytoskelet als belangrijke processen bij de activering van bloedplaatjes. Bovendien werden een aantal eiwitten die met die processen verbonden zijn, geselecteerd als mogelijke interessante doelen om de activering van bloedplaatjes 'uit' te zetten. 
In het laatste Hoofdstuk 9 hebben we de belangrijkste bevindingen van dit proefschrift besproken in relatie tot de huidige literatuur. We benadrukten dat bloedplaatjes een sleutelrol spelen in de pathofysiologie van hart- en vaatziekten waarin trombose en vaatontsteking met elkaar verweven zijn. Directe en indirecte communicatie tussen bloedplaatjes en andere vasculaire cellen is daarbij essentieel, en in het bijzonder de uitscheiding van granules, vesikels en moleculen uit bloedplaatjes. 